\title{
EXPLORING BRAND PREFERENCES OF SLOVAK CONSUMERS ACROSS DEMOGRAPHIC FEATURES
}

\author{
LUCIA VILČEKOVÁ', MIROSLAV SABO" \\ Comenius University', Slovak University of Technology in Bratislava", Bratislava, Slovakia
}

\begin{abstract}
The paper describes brand buying behavior of Slovak consumers across different demographic features with emphasis on domestic versus foreign brands. First, the introduction to brands and branding is provided, followed by description of purchase decision process and finally, research results are presented. The representative research was conducted in year 2013 on a sample of 1067 Slovak consumers older than 16 years of age. A relationship between age and attitudes toward brands was determined. Young people prefer foreign brands and country of origin is more important for them as for older consumers. The size of a city where people live does not have any influence on their brand preferences. Differences within gender were found, men prefer domestic products and women think foreign brands are more available. Women buy Slovak products because they want to support the economy.
\end{abstract}

\section{JEL CLASSIFICATION \& KEYWORDS}

M310 - BRAND PREFERENCES — DOMESTIC BRANDS
FOREIGN BRANDS - SLOVAK CONSUMERS

\section{INTRODUCTION}

Brands in marketing are used to differentiate products and services. According to American Marketing Association Dictionary (2013) brand is a "name, term, design, symbol, or any other feature that identifies one seller's good or service as distinct from those of other sellers". As Kotler and Keller (2009) write brand is a way of differentiating a company's goods, or services, from those of its competitors. Healey (2008) states "brand is a promise. It is .... an unwritten contract between a seller and a buyer...".

According to Klaming (2006) brand has an important role in consumer purchase decision process. Prior to a purchase the brand can increase consumer's efficiency of perception, processing and storage of information. The actual decision making activity can be easier because brands reduce uncertainty and reduce risk of a purchase and in the post purchase stage, the image benefits of brands emerge.

Consumer behavior can be described as determining why, when, how and who buys specific products or services. Marketers use the knowledge from psychology and sociology to be able to understand how people's mind works. Because no matter how similar people are, they make different purchase decision and the role of marketers is to find out how they decide and what factors influence their decisions. Thus, the purchase decision process is the same for everyone. One of the most recognized models describing consumer's purchase decision process is a five-stage model form Engel, Blackwell and Miniard (1986):

- Need recognition - Lindquist and Sirgy (2011) say it is a psychological process when consumer realizes a gap between his actual state and desired stage. The greater

I lucia.vilcekova@fm.uniba.sk

"miro165sabo@gmail.com the perceived distance, the more likely the consumer recognizes the need.

- Search for information - after recognizing the need, a buyer searches for information that will help to satisfy his need, as Pride and Ferell (2012) write. They add that information search has two aspects - internal information (memory of the consumer and previous experience) and external information (information from consumer's surroundings, e.g. friends, family, internet).

- Evaluation of alternatives - this stage is a pre-purchase evaluation according to Lantos (2011) when consumers compares and evaluate criteria and attributes of various alternatives they gathered during information search.

- Purchase decision - Boone (2013) describes this stage as when consumer evaluated all alternatives based on his own personal set of criteria and narrowed the alternatives down to one.

- Post-consumption evaluation - after the purchased consumer faces the evaluation of his action, if the product or service met, exceeded or is below his expectations.

This process has five stages, however, consumers do not necessarily need to go through all of them. It depends on the level of involvement. Low involvement products are products where consumers do not go through all the stages e.g. impulse buying, inexpensive products with low risk to the buyer if he makes a bad decision, automatic buying of routine products. By contrast, high involvement products are complex, have a high risk to the buyer in case of a wrong decision and such products are not purchased often. In this case, the consumer goes through the whole process of purchase decision and he engages in extended problem solving (www.saylor.org).

Level of involvement belongs to personal factors that differ from consumer to consumer and influence the buying decision process. Other personal factors are situational factors and demographic factors.

Lee (2006) explains that situational factors are external conditions that can influence the purchase decision. Sometimes an unexpected situation can be a trigger for purchase, or even can stop consumer from buying. Demographic factors, such as gender, age, income level, educational level, etc, also play an important role in consumer's purchase decision process and can cause deviation from general patterns of consumer decision making in different demographic variables.

Man and women behave differently, they want different products and they are likely to have different ways of liking and obtaining these. Gender has an important role in consumer behaviors. Because, the differences between men and women about expectation, want, need, life-style etc. reflect to their consumption behaviors (Swarna, 2012). According to Lee (2005). For instance, studies have revealed that gender, education, income and age differentiate the consumers' information search process. 
Men are less likely than women to complain when they are dissatisfied with a good or service in comparison to women they do not spread word of mouth and they are significantly less likely than women going to use specialist magazines as a source of information.

\section{Material and Methods}

In this paper, partial results from representative research of Slovak brand buying behavior are being presented. The data was collected from January to April 2013 with a questionnaire. Respondents were presented with a list of 24 statements concerning their attitudes towards domestic and foreign brands and their brand buying behavior. Likert scales, as a very common and easy tool for measuring attitudes, were used in the survey. The scales ranged from -2 (absolutely disagree) to +2 (absolutely agree).

The population in the research were Slovak consumers 16 years of age and older. To be able to draw conclusions form the research and to get accurate results, quota sampling was used. It ensures that chosen subgroups are represented in the sample to the exact extent as they are in the population. The quotas of this research were gender, age, education, and income reflecting the distribution in Slovak population.

The number of respondents was set to 1067 in order to get permissible error of 3 percent and confidence level of 95 percent for the research results.

The data were evaluated in $\mathrm{R}$, software for statistical computing and graphics. The techniques used in $\mathrm{R}$ were factor analysis followed by correlation matrix and comparison of demographic data with results of factor analysis.

\section{Results and Discussion}

As a first step, factor analysis was conducted in order to reduce the data to get more accurate results and also to easier compare the brand attitudes to demographic data. Since some statements in the research were similar or interrelated, there was a need to reduce these data into smaller set. The initial number of statements in the questionnaire was 24. The number of factors was determined by parallel analysis and Kaiser criterion. According to both techniques, the optimal number of factors was six.

\section{Factor 1 - Preferring Slovak brands}

Statements in Factor one favor Slovak brands. It is important for people to buy Slovak products, they usually prefer Slovak brands, and they trust Slovak brands and think these brands have better quality than foreign. They are also willing to pay more for Slovak products and they buy Slovak brands because they like Slovakia.

\section{Factor 2 - Foreign brands are better}

Typical for this factor are positive feelings towards foreign brands. Foreign brands are seen to have better quality, are more trustworthy, people have better experience with them and they usually go to shops with foreign brands.

\section{Factor 3 - Do not care about brands}

This factor represents no preference in brands. Brands are not important in buying decision process; people usually prefer cheap products and do not care about the brand.

Factor 4 - Carrying about country of origin

Statements in Factor four are related to products' country of origin. It is important where products are made, people take time to find out some information about country of origin

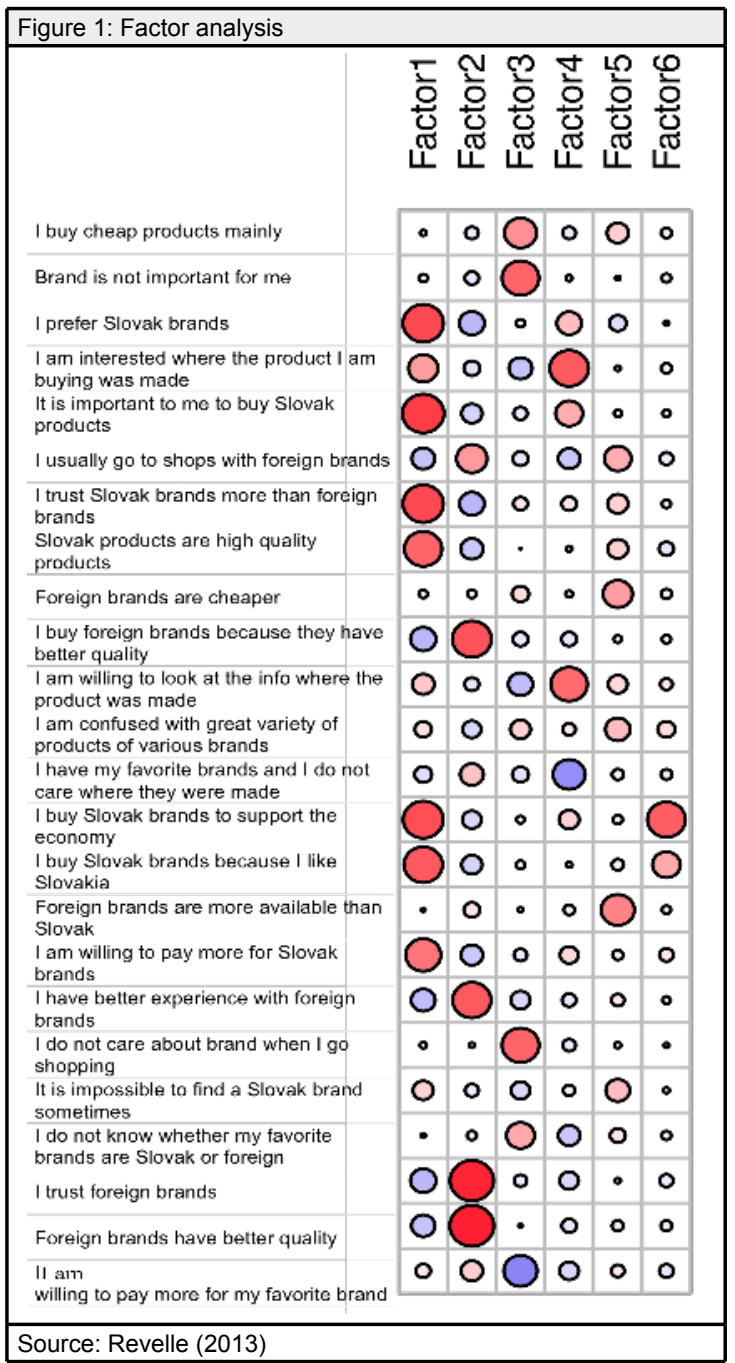

and they mostly prefer Slovak products, but also buy brands based on their previous experience.

\section{Factor 5 - Foreign brand are more available}

There are four main statements in Factor five showing us that foreign brands are perceived to be more available and cheaper than Slovak brands, people usually go to shops with foreign brands and they feel confused with great variety of brands, sometimes.

\section{Factor 6 - I love Slovakia}

The most significant features for this factor are buying Slovak brands to support the economy and buying Slovak brands because of positive feelings for Slovakia.

From the correlation matrix (figure 2) we can see strong negative correlation between age and Foreign brands are better and Do not care about brands and Carrying about country of origin. That means the younger consumers are, the more they prefer foreign brands because of their quality. The older the consumers are, the less they care about brands and young consumers pay more attention to the country of origin than the older. Education is positively correlated to Preferring Slovak brands which means that for consumers with higher education is important to buy Slovak products because they have better quality than foreign. There also is a positive correlation between education level 


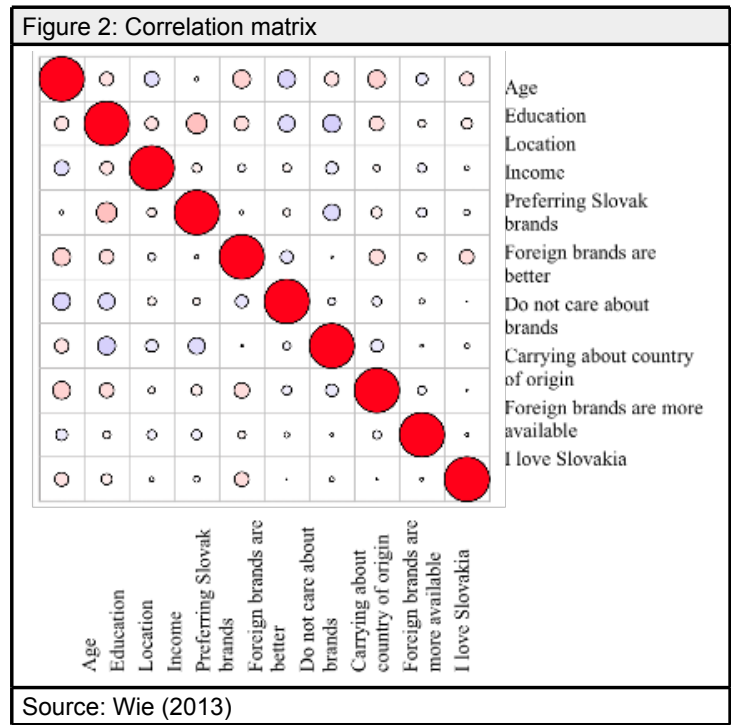

and not having any brand preferences at all. Location, that is size of a city where people live, is not correlated to any of the factors. Income shows some mild negative correlations with not carrying about brands - brands are not important factor in buying decision process of consumers with lower income.

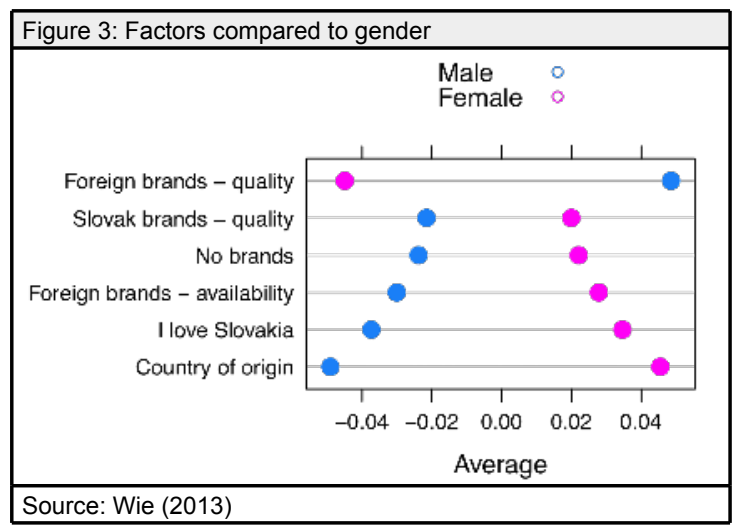

When we take a closer look to gender in comparison with the factors of buying behavior, we can see slight differences between men and women. The most significant difference is in Preferring foreign brands because of their quality, where females are more likely not to prefer these brands and men agree that they choose foreign brands because they trust these brands and they have good experience with these products. Describing the attitudes of men towards brands we can say they have neutral feeling toward the quality of Slovak products and to preferring domestic or foreign brands. They do not care about the country of origin when they shop and they do not think foreign brands are more available than Slovak. They do not have positive feelings for Slovak brands and they do not buy these products to support the economy. Women do not differ from man in their opinion on quality of foreign products and brands. Unlike men, they do care about where the brands they buy were produced, they think foreign brands are more available and they shop for Slovak brands because they like Slovakia.

\section{Conclusion}

Brands are projected values in the minds of customers and without this psychological commitment there are just unrecognizable products or services. Therefore, Temporal (2010) says, brand is commitment and marketers need to understand consumer and how his mind works to be able to build a real relationship between consumers and products. Greifenberg (2009) and Smolková (2006) add that understanding of consumer behavior frames a brand's competitive advantage. Considering demographic factors and brand buying behavior, there is a relationship between age and attitudes toward brands, where young people prefer foreign brands and country of origin is more important for them as for older consumers. The size of a city where people live does not have any influence on their brand preferences and there was also just mild correlation between income and brand preference. When we compare men and women, men prefer domestic products and women think foreign brands are more available and the buy Slovak products because they want to support the economy.

For further analysis, statistical tests can be performed for every demographic variable in contrast with factor analysis results. This will show dependence or independence of demographic variables and brand buying behavior of Slovak consumers on a statistical significant level.

\section{Acknowledgements}

This article has been elaborated as one of the outcomes of research project VEGA 1/1051/11 "Analysis of the strategic process of brand building and brand management in the context of homogenization and individualization of consumer needs".

\section{References}

American Marketing Association Dictionary. (2013). Retrieved from http://www.marketingpower.com/_layouts/dictionary.aspx?dLetter=B Boone, L. (2013). Contemporary Marketing, Cincinnati: SouthWestern.

Engel, J., \& Blackwell, P. \& Miniard, P. (1986.) Consumer Behavior, Dryden Press.

Greifenberger, E. (2009). The Hub magazine. Retrieved from http://hubmagazine.com/archives/the_hub/2009/jul_aug/the_hub31 rak.pdf

Healey, M. (2008.) What is Branding?, Mies: RotoVision.

Klaming, G. (2006). The changing role of brands in the age of empowered consumers. Retrieved from http://www.markenlexikon. com/d_texte/klaming_changing_role_of_brands_2006.pdf

Kotler, P., \& Keller, K.L. (2009). Marketing Management, Praha: Grada.

Lantos, G. (2011). Consumer Behavior in Action: Real-Life Applications for Marketing Managers, NY: M.E.Sharpe.

Lee, H. S. (2005). An Application of a Five-Stage Consumer Behaviour Decision Making Model: An Exploratory Study of Chinese Purchasing of Imported Health Food. Retrieved from http://summit.sfu.ca/item/4741

Lindquist, J., \& Sirgy, J. (2011). Shopper, Buyer and Consumer Behavior: Theory and Marketing Applications, New Delhi: DEL.

Pride, W., \& Ferrell, O. (2012). Marketing, Ohio: Cengage Learning.

Revelle, W. (2013). Procedures for Personality and Psychological Research. Retrieved from http://CRAN.R-project.org/package=psych Version $=1.3 .2$

Smolková, E. (2006). Strategický brand manažment a jeho aktuálne úlohy. Marketing Inspirations; 1 (3): 9-12.

Saylor.org. (2013). Consumer Behavior: How People Make Buying Decisions. Retrieved from http://www.saylor.org/site/wp-content/ uploads/2013/02/BUS203-PoM-Ch3.pdf

Swarna, B. (2012). Impact of gender on consumer purchase behavior. Journal of commerce and management; 1 (9): 10-18.

Temporal, P. (2010). Advanced Brand Management: Managing Brands in a Changing World, Singapore: John Wiley \& Sons.

Wie, T. (2013). Corrplot: Visualization of a correlation matrix - R package version 0.71 . Retrieved from http://CRAN.R-project.org/ package $=$ corrplot 